\title{
Second contribution to the knowledge of the Lithosiini of Gabon: the genus Nanna Birket-Smith (Lepidoptera, Erebidae, Arctiinae)
}

\author{
Antonio DURANTE ${ }^{1}$, Emelie Arlette APINDA-LEGNOUO ${ }^{2} \&$ Chiara ROMANO $^{3}$ \\ ${ }^{1}$ Museo di Storia naturale del Salento. Via Europa 95, 73021 Calimera, Italy \\ Email: antonio.durante@msns.it (corresponding author) \\ ${ }^{2}$ Institut de Recherches sur l'Écologie Tropicale, Libreville, Gabon \\ Email: ea.apindalegnouo@yahoo.fr \\ ${ }^{3}$ Viale Santa Caterina Novella 26, 73013 Galatina, Italy \\ Email: chiararomano@,virgilio.it \\ ${ }^{1}$ urn:1sid:zoobank.org:author:EE002752-B8CA-40FA-A6B2-02B46375D850 \\ ${ }^{2}$ urn:lsid:zoobank.org:author:BC3E3E0E-D9C9-4664-AE16-709F8DA33D8F \\ ${ }^{3}$ urn:Isid:zoobank.org:author:A882257F-26A4-4493-8522-B1E22561E933
}

\begin{abstract}
The presence of the genus Nanna in Gabon is treated. Four species are recorded, two of which are new to science ( $N$. molouba sp. nov. and N. semigrisea sp. nov.), and the hitherto unknown female of Nanna ceratopygia is described. A checklist and a key to the species of the genus Nanna are provided.
\end{abstract}

Keywords. Arctiinae, Lithosiini, Nanna, new species, Afrotropical Region.

Durante A., Apinda-Legnouo E.A. \& Romano C. 2013. Second contribution to the knowledge of the Lithosiini of Gabon: the genus Nanna Birket-Smith (Lepidoptera, Erebidae, Arctiinae). European Journal of Taxonomy 65: 1-15. http://dx.doi.org/10.5852/ejt.2013.65

\section{Introduction}

This second contribution on the Lithosiini of Gabon (the first one is Durante 2012) deals with the presence of the genus Nanna Birket-Smith, 1965 in the Ivindo National Park (North-eastern Gabon).

This genus was proposed by its author mainly based on West African material: Kiriakoff(1963) described Lithosia colonoides (Kiriakoff, 1963) from Democratic Republic of the Congo and recently Kühne (2005, 2007) extended its range to East Africa (see list below). Hitherto it has not been recorded from Gabon.

The genus was diagnosed by its author by means of the irregular weak sclerotizations of the aedeagus and the absence of the valvellae; he also added (Birket-Smith 1965:35) a small plate-like cornutus in the vesica, the vinculum not forming any saccus, and the distally rounded, membranous supravalva.

With the present contribution, the number of Nanna species rises to 13, two of which are newly recorded from Gabon and two more are here described as new.

A key to the species of the genus Nanna is provided below. 


\section{Material and methods}

All the Gabonese material used for this paper comes from the moths collected by the first and second authors in the National Park of Ivindo, during the short rainy season from February to April.

The Park, in the North-East of Gabon at about $500 \mathrm{~m}$ a.s.l., has an extension of 300000 ha, most of which is covered by primary forest and is drained by a lot of watercourses, the most important being Ivindo, the major, Djidji and Langoué (Vande Weghe 2006). The Ipassa Research Station, the place of the captures, is in the far north of the park, and the forest around is somewhat degraded with residual primary forest, old and young secondary forest, and bush and crop areas. The Ivindo National Park presents a forest with transitional characteristics between the Western Congolese forest with Atlantic influences and the real Western Congolese forest, without a clear line of demarcation (Vande Weghe 2010). The climate is equatorial with two wet seasons (a short one from February to April/May, and a longer one from August to November), a short dry season in December-January, and a long dry season from May/June to July/August.

The moths were attracted at night using three blended light lamps of 500 watt placed at about $200 \mathrm{~m}$ from each other, in front of a white cotton sheet. The collection started actively from 7 p.m. to about midnight. Much material was also collected in the morning on and around the white sheets.

One sheet was positioned in front of the secondary forest around the station, the second one in front of the Ivindo River on the top of a slope high over the primary forest canopy (Fig. 1), and the third one facing the research station inwards (Fig. 2).

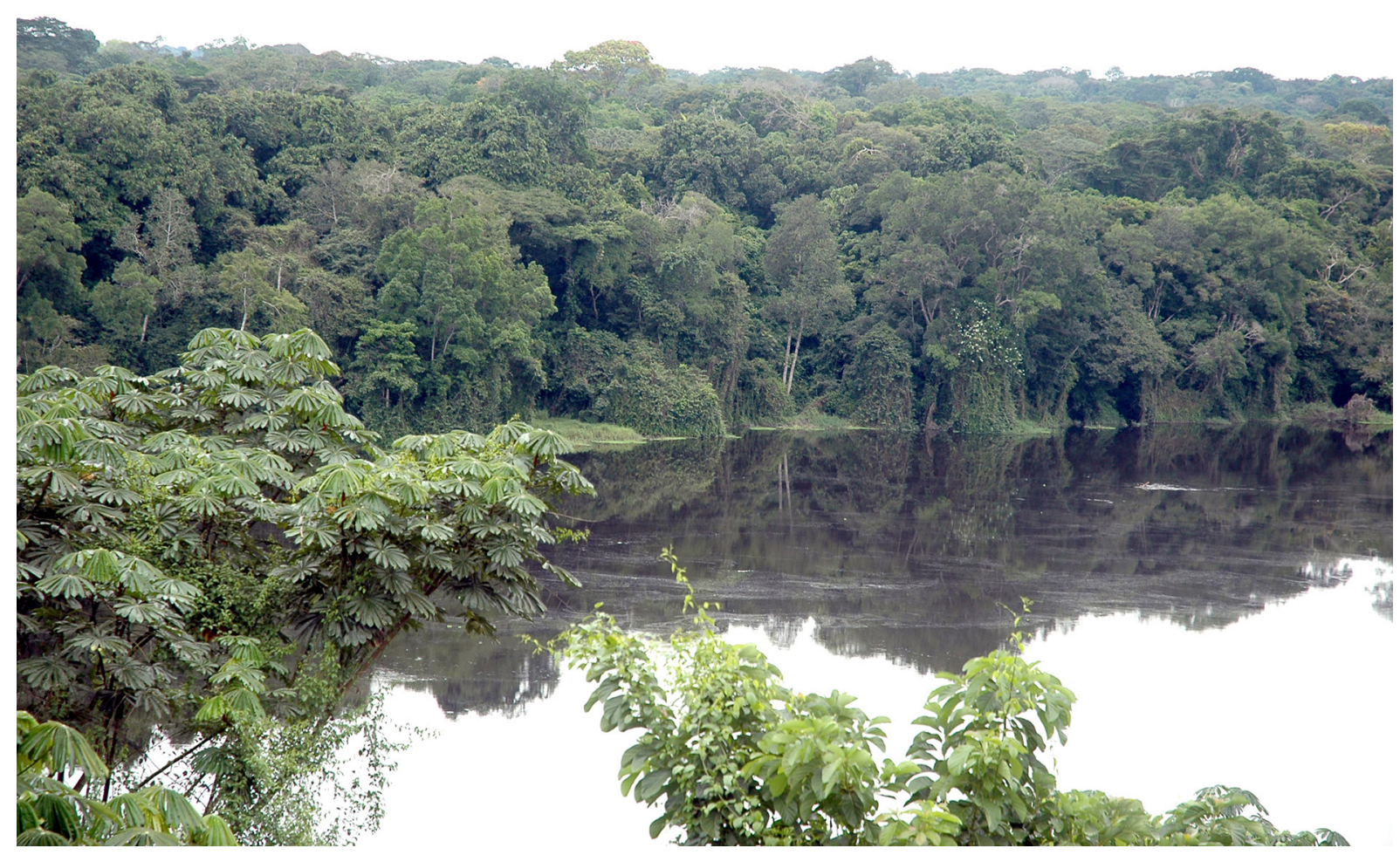

Fig. 1. Primary forest on the Ivindo River at the Ipassa research station. Courtesy of Piero Carlino. 
The Lithosiini moths were killed immediately after capture, using ammonia vapours, and pinned the following morning. After a few months, the moths were rehydrated and spread with standard methods (e.g., Winter 2000).

Genitalia were dissected according to Durante (2008).

Pictures were taken in the field (landscapes) and in the laboratory (adults) with a digital camera; genitalia were photographed and mounted under a trinocular stereomicroscope. The pictures were improved using the software Photoshop CS4.

Pictures of genitalia are not in due proportion.

Genitalia terminology according to Birket-Smith (1965), Klots (1970), Tikhomirov (1979) and Kristensen (2003).

The material is stored at the MSNS and the first author's collections.

\section{Abbreviations}

$\begin{array}{ll}\text { ANPN } & \text { Agence Nationale des Parcs Nationaux, Gabon } \\ \text { BMNH } & =\text { The Natural History Museum, London, United Kingdom } \\ \text { CENAREST } & \text { Centre National de la Recherche Scientifique et Technologique, Gabon } \\ \text { D.R.C. } & =\text { Democratic Republic of the Congo } \\ \text { IRAF } & =\text { Institut de Recherches Agronomiques et Forestières, Gabon } \\ \text { IRET } & =\text { Institut de Recherches sur l'Écologie Tropicale, Gabon }\end{array}$

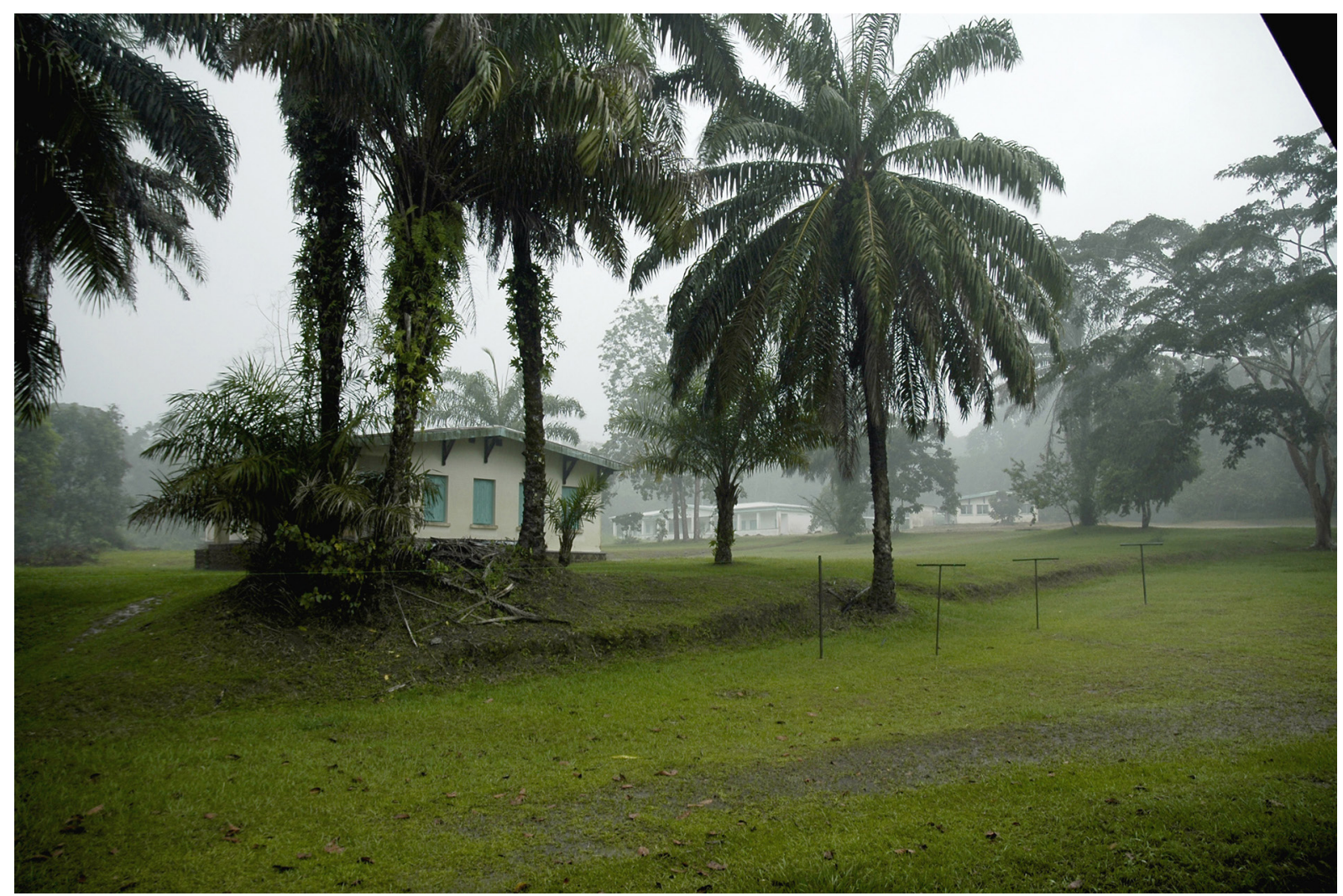

Fig. 2. The Ipassa research station in Ivindo National Park. 


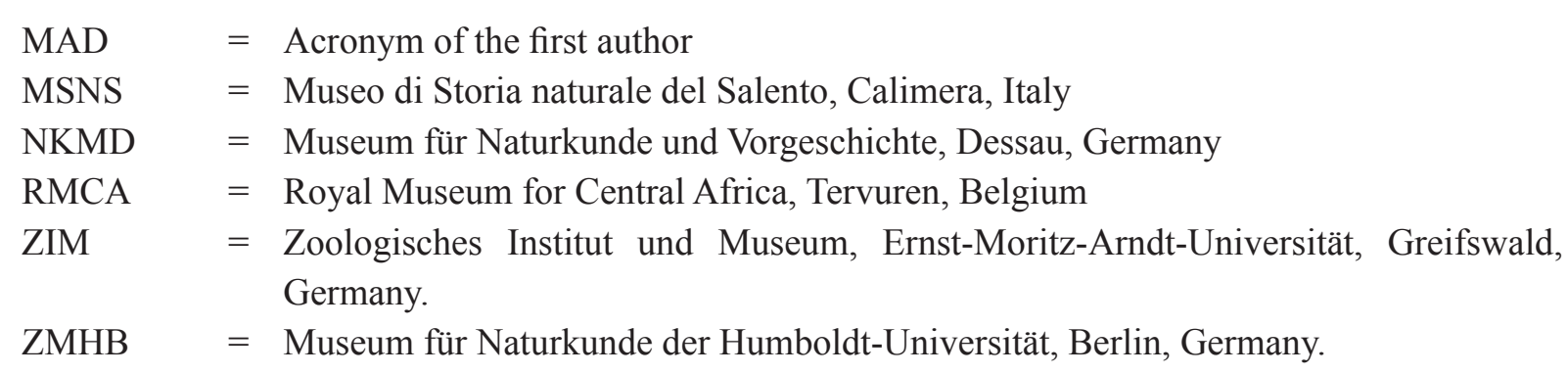

\section{Results}

Phylum Arthropoda Latreille, 1829

Class Insecta Linnaeus, 1758

Order Lepidoptera Linnaeus, 1758

Family Erebidae Leach, [1815]

Subfamily Arctiinae Leach, [1815]

Tribus Lithosiini Billberg, 1820

Genus Nanna Birket-Smith, 1965

At present, the genus Nanna includes 13 species of which two are newly recorded for Gabon, N. ceratopygia Birket-Smith, 1965 and N. eningae (Plötz, 1880), and two are endemic in Gabon (N. molouba sp. nov. and N. semigrisea sp. nov.).

\section{Remarks}

In the original paper, Birket-Smith does not provide any information about the etymology and grammatical gender. It is very probably derived from the name "Nanna", the god of the moon in Sumerian mythology. That name should be masculine, but the author treats it as feminine, making it agree with the specific names, such as magna. According to the art. 30.2.3 of ICZN, the genus name Nanna has to be considered feminine.

\section{Checklist of species belonging to the genus Nanna}

Nanna ceratopygia Birket-Smith, 1965

Nanna collinsii Kühne, 2007

Nanna colonoides (Kiriakoff, 1963)

Nanna diplisticta (Bethune-Baker, 1911)

Nanna eningae (Plötz, 1880)

Nanna griseata Kühne, 2007

Nanna kamerunica Kühne, 2007

Nanna loloana (Strand, 1912)

Nanna magna Birket-Smith, 1965

Nanna melanosticta (Bethune-Baker, 1911)

Nanna molouba sp. nov.

Nanna naumanni Kühne, 2005

Nanna semigrisea sp. nov.
Nigeria, Cameroon, Gabon (type in BMNH)

D.R.C., Kenya (type in RMCA)

D.R.C. (type in RMCA)

(type species) Nigeria, Cameroon, Angola, (type in $\mathrm{BMNH})$

Ivory Coast, Togo, Nigeria, Cameroon, Gabon (type in ZIM)

Ivory Coast (type in RMCA)

Cameroon (type in NKMD)

Cameroon (type in ZMHB)

Cameroon (type in its author's collection)

Ghana, Angola (type in BMNH)

Gabon (type in MSNS)

Kenya (type in its author's collection)

Gabon (type in MSNS) 


\section{Key to the males of the species of Nanna}

The following key is based mainly on the genitalia because the habitus of the species included in the genus Nanna is very similar. Furthermore the females are not included due to our fragmented knowledge about them.

1. Forewings ochreous yellow Nanna ceratopygia Birket-Smith, 1965

- Forewings white or light grey.....

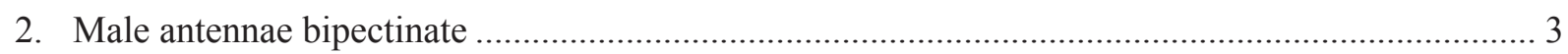

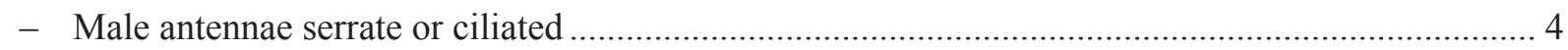

3. Ala valvae of the male genitalia with a triangular process at its distal third

Nanna molouba sp. nov.

- Ala valvae of the male genitalia without a triangular process

Nanna magna Birket-Smith, 1965

4. Male genitalia processus basalis plicae clearly noticeable (1st group of B.-S. 1965) ..................... 5

- Male genitalia processus basalis plicae not noticeable or absent (2nd group of B.-S. 1965).......... 12

5. Processus basalis plicae from half length of valva up to longer than the entire valva 6

- Processus basalis plicae shorter than half length of valva.

6. Supravalva spatulate and clearly shorter than ala valvae Nanna loloana (Strand, 1912)

- Supravalva as long as or longer than ala valvae....

7. Ala valvae distally bent in U-shape Nanna ceratopygia Birket-Smith, 1965

- Ala valvae tapering and just smoothly bent 8

8. Processus basalis plicae longer than supravalva, S-shaped Nanna naumanni Kühne, 2005

- Processus basalis plicae shorter than supravalva, almost straight

9. Uncus strong and long Nanna diplisticta (Bethune-Baker, 1911)

- Uncus slender and short. Nanna colonoides (Kiriakoff, 1963)

10. Aedeagus slender (eight times longer than broad) Nanna griseata Kühne, 2007

- Aedeagus normally sized (less than five times longer than the average width)

11. Processus basalis plicae deeply falcate Nanna semigrisea sp. nov.

- Processus basalis plicae less curved and shorter Nanna collinsii Kühne, 2007

12. Supravalva very large, ear-like Nanna kamerunica Kühne, 2007

- Supravalva slender and long..... 13

13. Distal process of the ala valvae slender and long Nanna eningae (Plötz, 1880)

- Distal process of the ala valvae short and stubby .Nanna melanosticta (Bethune-Baker, 1911) 
Account of the Gabonese species

Nanna ceratopygia Birket-Smith, 1965

Figs 3A-B, 4A, 5A

Nanna ceratopygia Birket-Smith, 1965: 40-42.

\section{Type material}

Holotype

$\widehat{\jmath}, \mathrm{BMNH}$, examined.

\section{Allotype}

ㅇ, GABON: Makokou-Ipassa, 500 m, 0³0’43”N, 1248’13’'E, 16-28 Feb. 2012; gen. prep. n. 730/13 MAD, MSNS.

\section{Type locality}

Bitje, Ja river, Cameroons, leg. Joyce? 1915.

\section{Other material examined}

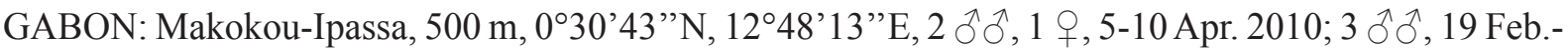
11 Mar. 2011; 5 ๙ิฮึ, 1q, 16-28 Feb. 2012; MSNS and MAD.

\section{Description}

\section{Habitus}

Wingspan: + 39-44 $\mathrm{mm}$. General aspect similar to the male, larger and with a bigger abdomen.

\section{Genitalia}

Seventh segment slightly sclerotized, one and a half times longer than the sixth segment; the sternite with a deep concavity in the middle of its caudal margin to accommodate the sterigma; pleurae with one triangular membranous thickness, cephalad with a shallow pouch consisting of membranous thick tissue. Eighth segment slightly sclerotized, as long as the sixth one; sternite with two membranous lateral shallow concavities and the central portion forming a well sclerotized squarish lamella postvaginalis. Anterior apophyses very short, about one third as long as the eight segment; posterior apophyses two times longer than the anterior ones. Dorsal pheromone glands a little longer than the posterior apophyses.

Ostium bursae membranous, no lamella antevaginalis. Ductus bursae almost as long as large broad, internally covered by spiculate thorns; its caudal portion naked, with a small dorsal dome-shaped appendix holding the ductus seminalis. Corpus bursae lenticular, internally covered by spiculate thorns except around the signum. Signum concave, roundish, with small thorns.

\section{Distribution}

Cameroon (type locality, Birket-Smith 1965). Nigeria (Birket-Smith 1965); Gabon (new locality).

\section{Remarks}

This species, hitherto only known from the type locality and Nigeria, is now also reported from Gabon. The female is recorded and hereafter described for the first time (an allotype is designed in the sense of ICZN art. 72.1.3, Recommendation 72A). 

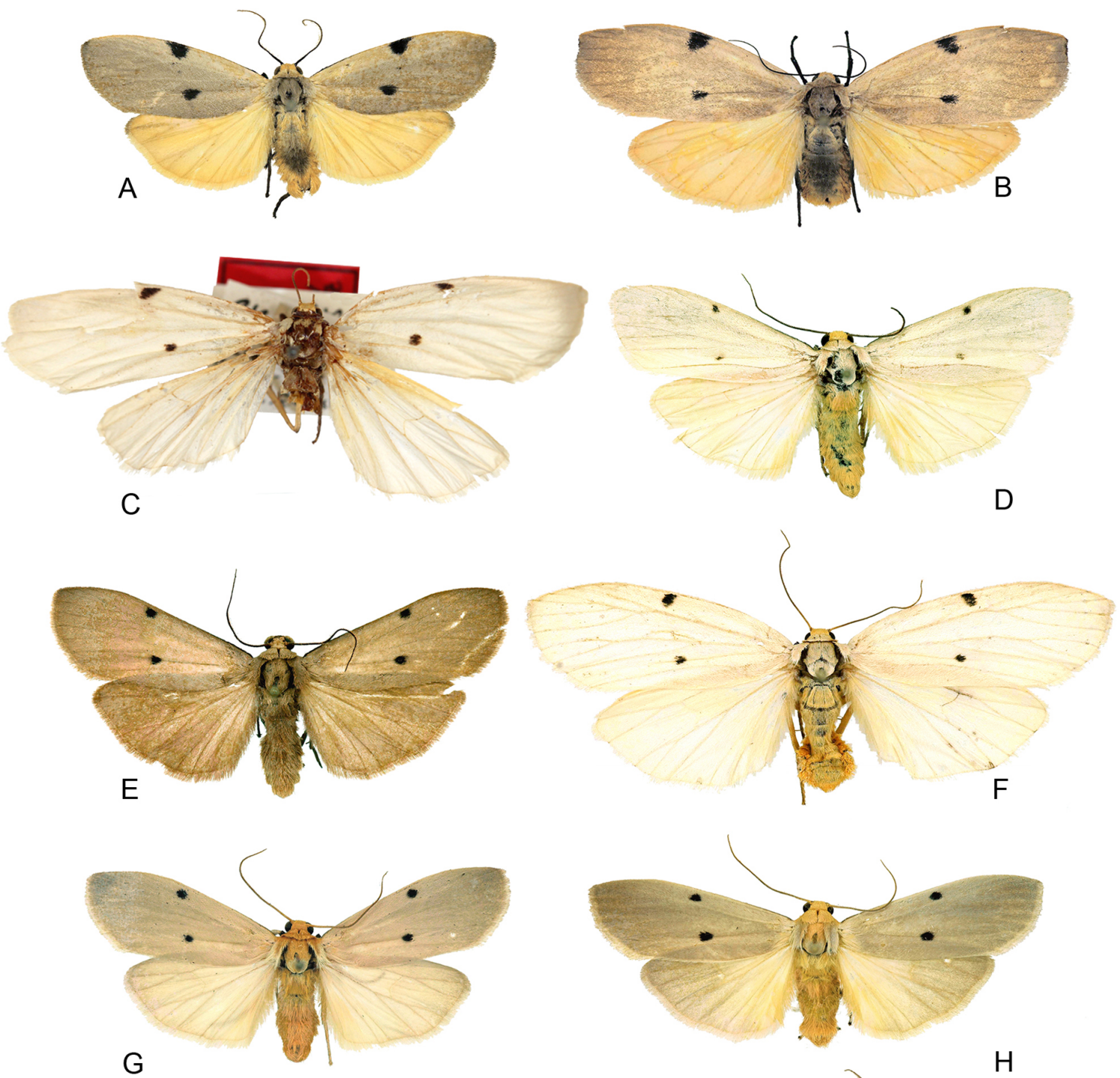

G

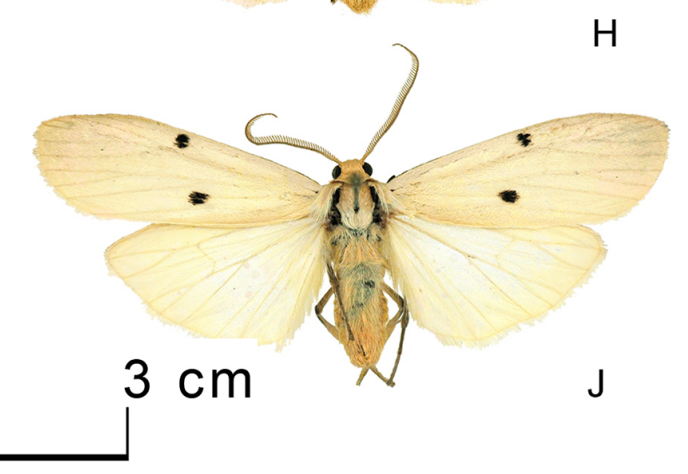

Fig. 3. Adults. A. Nanna ceratopygia Birket-Smith, 1965, O̊, Gabon, Makokou-Ipassa, $500 \mathrm{~m}, 0^{\circ} 30^{\prime} 43$ ”'N 1248'13”'E, 19 Feb.-11 Mar. 2011. B. Nanna ceratopygia, q allotype. C. Nanna eningae (Plötz, 1880), q holotype. D. Nanna eningae, ô, Gabon, Makokou-Ipassa, 500 m, 0³0’43”N 12॰48’13”E, 19 Feb.11 Mar. 2011, gen. prep. n. 697/12 MAD. E. Nanna eningae, đ, Gabon, Makokou-Ipassa, 500 m, $0^{\circ} 30^{\prime} 43$ "N 12 48'13”'E, 16-28 Feb. 2012, gen. prep. n. 705/12 MAD. F. Nanna eningae,, , Gabon, Makokou-Ipassa, $500 \mathrm{~m}, 0^{\circ} 30^{\prime} 43^{\prime} \mathrm{N} 12^{\circ} 48^{\prime} 13^{\prime}$ E, 5-10 Apr. 2010. G. Nanna semigrisea sp. nov., $0^{\Uparrow}$ paratype, gen. prep. n. 709/12 MAD. H. Nanna semigrisea sp. nov., ô paratype, gen. prep. n. 708/12 MAD. I. Nanna semigrisea sp. nov., + paratype, gen. prep. n. 699/12 MAD. J. Nanna molouba sp. nov., $\delta$ holotype. 


\section{Nanna eningae (Plötz, 1880)}

Figs 3C-F, 4B, 5B

Gnophria eningae Plötz, 1880: 80.

Eilema eningae var. pia Strand, 1912: 99-100.

Nanna montana Birket-Smith, 1965: 44-45; synonymized by Kühne (2005).

Ilema eningae - Hampson 1900: 156.

Nanna pia - Birket-Smith 1965: 43-44; synonymized by Kühne (2005).

\section{Type material}

Holotype,, , ZIM., only the picture examined.

\section{Type locality}

W. Africa, Eningo [Ivory Coast], 13 Jun. 1875, leg. R. Buckholz.

\section{Other material examined}

GHANA: Ashanti, Bobiri, 1 ô, 25 May 2011.

D.R.C: Eala, 1 Oૈ, Oct. 1936; Sankuru, 1 §ૈ, 25 Nov. 1951.

NIGERIA: Odi, 1 ○, 30-31 May 1997.

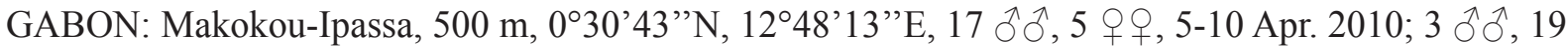
Feb.-11 Mar. 2011; 3 ठै ๙ै 16-28 Feb. 2012; MSNS and MAD.

\section{Distribution}

Ivory Coast (type locality, Plötz 1880); Ghana (RMCA coll.); Togo (Strand 1912); Nigeria (BirketSmith 1965; Durante \& Panzera 2001); Cameroon (Strand 1912; Birket-Smith 1965); DRC (RMCA coll.); Gabon (new locality).

\section{Remarks}

Kühne (2005) synonymized Nanna montana and N. eningae var. pia with $N$. eningae based on the variability of the wing colour and the colour pattern of $N$. eningae (see Kühne 2007: 354), and on comparisons with the type of $N$. eningae (Kühne 2007: 354), disregarding the male genitalic differences described by Birket-Smith between N. montana and N. pia. They were probably considered to represent only a minor intraspecific variability. According to Birket-Smith $(1965: 43,47)$, the types of $N$. eningae and N. pia were untraceable, but Kühne (2005) explained that he was able to compare his specimens of N. eningae and N. pia with the types in the Plötz collection. However, Kühne (2007) admitted to the possibility that the $N$. eningae-group is composed of several taxa, but he did not go further into this matter.

Durante \& Panzera (2001) did not provide clear distinctive characters for lack of material and classified a single specimen from Nigeria as $N$. montana, based on male genitalic morphology. In this respect, it should be remarked that one specimen from Ghana (RMCA collection) shows all the characteristics described by Birket-Smith (1965) about $N$. pia, leading to the conclusion that the variability between $N$. pia (eningae) and N. montana could be concrete.

At present, although the examined series from Gabon does not show any genitalic variability within itself (in contrast with the above supposed "minor intraspecific variability"), the conclusions of Kühne (2005) are here cautiously accepted, since the synonymy can be supported by the similarity of the Gabonese female genitalia with the ones of $N$. pia figured in Birket-Smith (1965) and the similarity of 


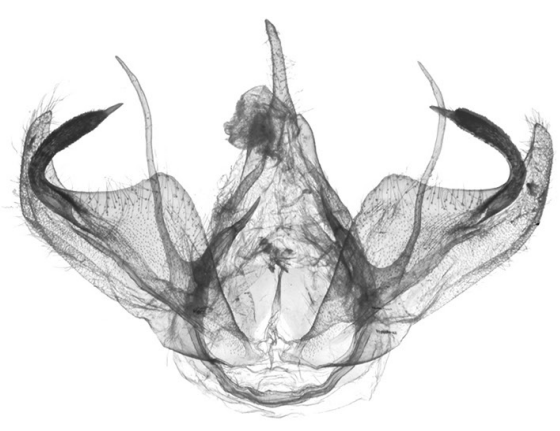

A
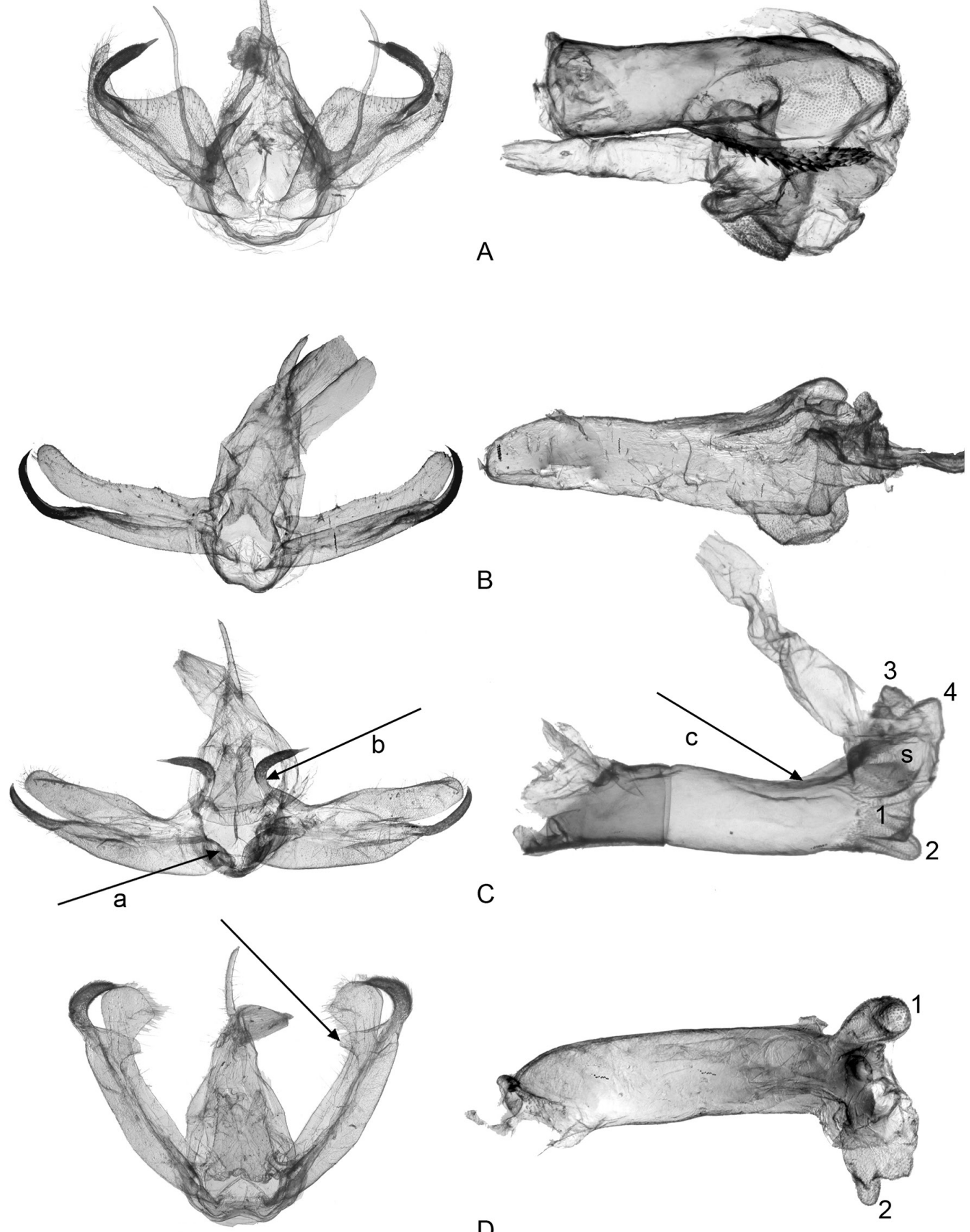

C

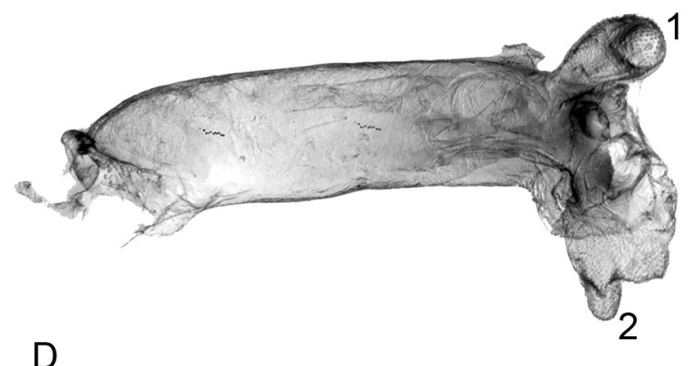

Fig. 4. Male genitalia. Figures are not in equal proportion; the aedeagus, on the right, is enlarged.

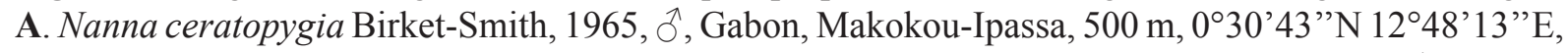
19 Feb.-11 Mar. 2011, gen. prep. nov. 729/13 MAD. B. Nanna eningae (Plötz, 1880), Oૈ, Gabon, Makokou-Ipassa, 500 m, 0³0’43”N 1248'13”'E, 19 Feb.-11 Mar. 2011, gen. prep. n. 697/12 MAD. C. Nanna semigrisea sp. nov., ô paratype, Gabon, Makokou-Ipassa, 500 m, 0³0’43”'N 1248'13”'E, 19 Feb.-11 Mar. 2011., gen. prep. n. 698/12 MAD. Arrows: $a=$ ventral sclerotization of the basis valvae; $b$ $=$ processus basalis plicae; $\mathrm{c}=$ distal sclerotized bar. $\mathrm{s}=$ tha moderate swelling in the vesica. $1-4=$ lobes of the vesica. D. Nanna molouba sp. nov., Ô paratype, Gabon, Makokou-Ipassa, $500 \mathrm{~m}, 0^{\circ} 30^{\prime} 43$ '” N 1248'13'"E, 5-10 Apr. 2010, gen. prep. n. 562/10 MAD. 
the Gabonese male genitalia with the ones of N. montana, both figured in Birket-Smith (1965) and in Durante \& Panzera (2001), in addition to the existing wing colour variability (see Fig. 3E).

Nanna semigrisea sp. nov. urn:Isid:zoobank.org:act:0B5D4B5E-108E-4376-990C-ED2DADD56869

Figs 3I, 4C, 5C

\section{Diagnosis}

Species quite distinguishable in the genus thanks to the light grey forewings and the usually paler hindwings; it is, however, very similar to Nanna griseata. Male genitalia similar to those of Nanna collinsii and $N$. griseata, but the processus basalis plicae is longer and more falcate in $N$. semigrisea sp. nov.; moreover, $N$. collinsi has shorter valvae and a larger aedeagus, $N$. griseata a more slender aedeagus.

\section{Etymology}

The name originates from the combination of the Latin prefix semi- (meaning "half") and the adjective griseus (meaning "grey").

\section{Type material}

\section{Holotype}

$\hat{\jmath}$, MSNS.

\section{Paratypes}

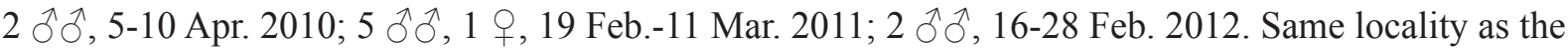
holotype. MSNS and MAD.

\section{Type locality}

GABON: Makokou-Ipassa, 500 m, 0³0’43”N, 1248’13” E, 19 Feb.-11 Mar. 2011.

\section{Description}

\section{Habitus}

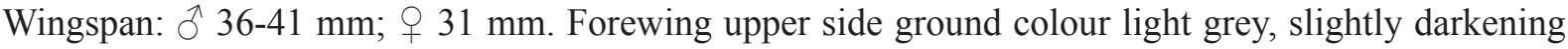
distally; costa with the proximal two fifths greyish; pattern with two black dots on the median area, one on the costal margin, and another one between the $\mathrm{CuA} 2$ and the anal vein. Hindwing upper side ground colour white, sometimes shading to grey toward the apex and termen. Forewing underside ground colour darker grey than the upper side, gradually shading to creamy white toward the base and the inner margin. Hindwing underside as in the upper side. Fringes of the same colour as that wing's ground colour.

Head ochreous yellow, labial palpi porrect, ochreous yellow male antennae ciliated, female filiform, ochreous yellow.

Patagia uniformly ochreous yellow, tegulae and notum ochreous yellow, shading posteriorly to greyish white. Thorax ventrally yellow.

Male legs light yellow with the distal end of the femur dark grey; forelegs with femur and tibia shading into light grey; in the female homogeneous light yellow. Praetarsi blackish. Spurs formula 0-2-4.

Abdomen greyish white, shading to ochreous yellow starting from about the sixth segment to the terminalia. 


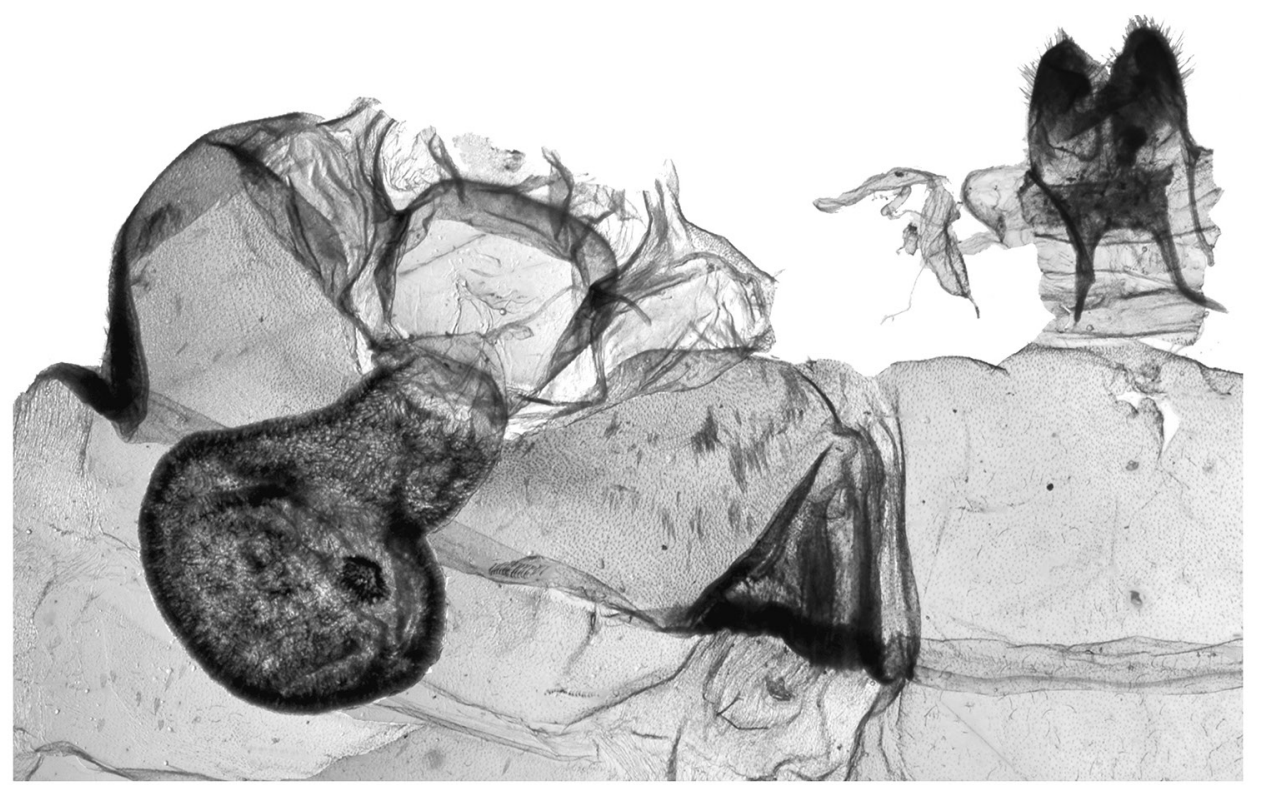

A
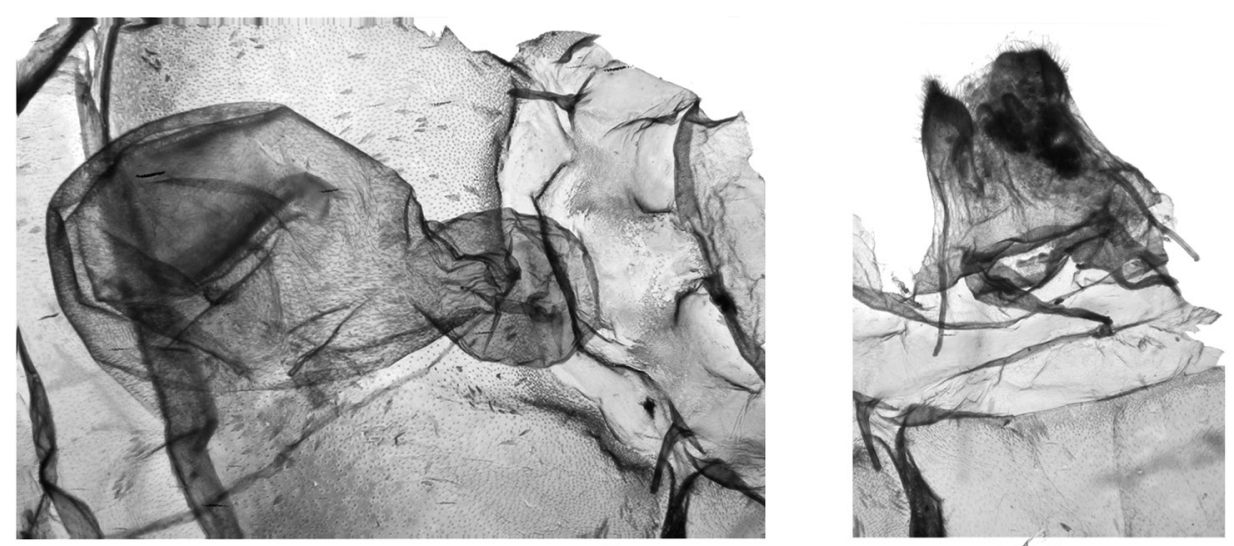

B

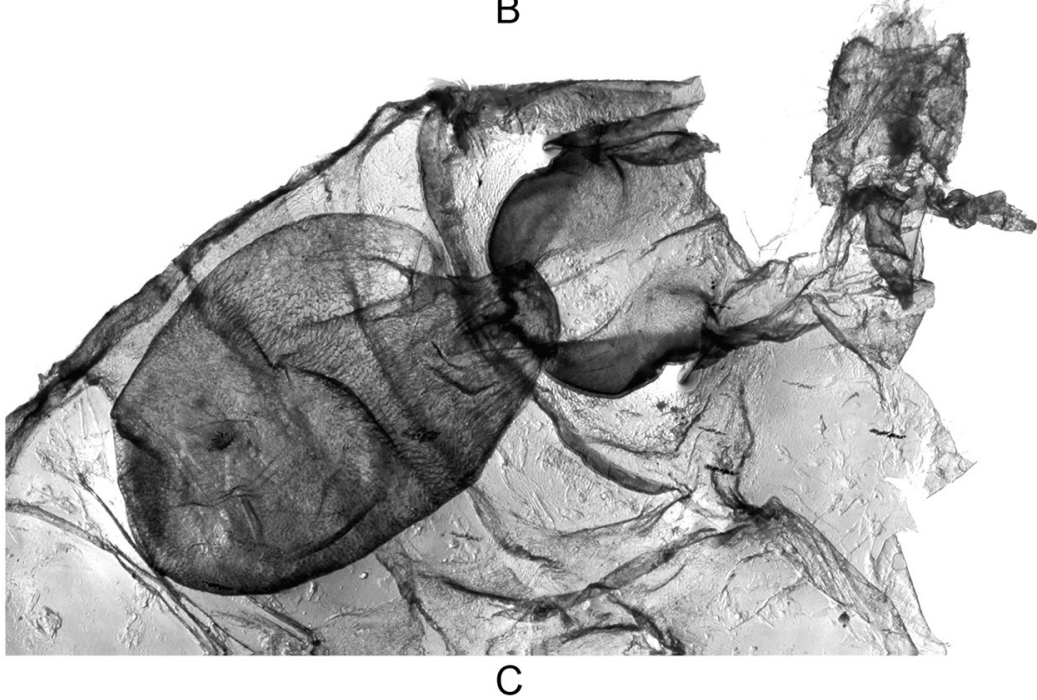

Fig. 5. Female genitalia. Figures are not in equal proportion. A. Nanna ceratopygia Birket-Smith, 1965, \& allotype. B. Nanna eningae (Plötz, 1880), + , Gabon, Makokou-Ipassa, 500 m, 0³0'43”'N $12^{\circ} 48^{\prime} 13$ ”E, 5-10 Apr. 2010, gen. prep. n. 558/10 MAD. C. Nanna semigrisea sp. nov., + paratype 


\section{Genitalia}

MALE. A8 medially membranous and laterally slightly sclerotized, length about one third that of the seventh segment.

Uncus slender, long, caudally bent, ending in a point; tegument pear-shaped (ventral view); vinculum semicircular, strong, with two ventral swellings if pressed under cover slide. Juxta great, upside down Y-shaped, well sclerotized.

Basis valvae ventrally sclerotized (a round bar-like sclerotization contiguous to the dorsal margin of the ala valvae, Fig. 4C, arrow a); medially membranous; dorsally well sclerotized, with a strong processus basalis plicae (tendon of Kühne 2007), deeply falcate, with its distal three fifths covered by dense tiny thorns, terminating with a strong spike (Fig. 4C, arrow b).

Ala valvae sclerotized, distally tapering. The distal process strongly sclerotized, covered by thorns dorsally for all its length and completed only on its last fourth, ending in a point.

Supravalva more membranous, finger shaped, just a little shorter than ala valvae.

Aedeagus quite narrow, partially membranous (pseudaedoeagus of Birket-Smith 1965), with a distal narrow sclerotized bar terminating in a curl. Vesica small, membranous, with two proximal (numbered 1 and 2 in Fig. 4C) and two distal ( 3 and 4 ) lobes covered by very small spines; opposite to the curl (arrow c), a moderate swelling (s).

FEMALE. Seventh segment slightly sclerotized, one and a half times longer than the sixth segment. Eighth segment about half as long as the sixth one, membranous. Anterior apophyses as short as the eight segment; posterior apophyses three times longer than the anterior ones. Dorsal pheromone glands a little longer than posterior apophyses.

Lamella postvaginalis present as a strong shield inserting cephalad in the seventh sternum, which surrounds the lamella with two lateral well evident folds.

Ostium membranous, with two small anterior swellings, which cannot be interpreted as lamellae antevaginalis.

Ductus bursae short, membranous with the dorsal wall strongly sclerified, triangularish.

Corpus bursae ovoid, internally covered by small slender thorns except around the signum, with a small dome-shaped posterior appendix; ductus seminalis arising from the appendix. Signum concave, oblong, covered by very tiny spines.

Nanna molouba sp. nov. urn:1sid:zoobank.org:act:2B2F8C94-2AA5-45E0-9A5B-DEF470A55E0D

Figs 3J, 4D

\section{Diagnosis}

Species similar to $N$. collinsi, $N$. colonoides, $N$. eningae and $N$. melanosticta, but easily distinguishable thanks to the bipectinate antennae of $N$. molouba sp. nov. Nanna magna also has bipectinate antennae, but its genitalia are clearly different. 


\section{Etymology}

This species is dedicated to the kind Dr. Aurelie Flore Molouba, head of the Scientific Commission of the CENAREST. Noun in apposition (ICZN article 11.9.1.2).

\section{Type material}

\section{Holotype}

ô, MSNS.

\section{Paratypes}

$5 \widehat{\partial}, 5-10$ Apr. 2010; 3 $\widehat{\partial}, 19$ Feb.-11 Mar. 2011. Same locality as the holotype. MSNS and MAD.

\section{Type locality}

GABON: Makokou-Ipassa, 500 m, 0³0’43”N, 1248’13”E, 19 Feb.-11 Mar. 2011.

\section{Description}

\section{Habitus}

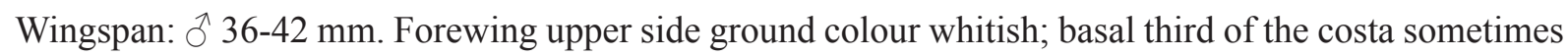
blackish; pattern with two black dots on the median area, one on the costal margin, and another one between the $\mathrm{CuA} 2$ and the anal vein. Hindwing upper side ground colour white. Forewing underside ground colour slightly darker than the upper side, with a creamy fascia along the costal margin. Hindwing underside as in the upper side. Fringes of the same colour as that wing's ground colour.

Head yellow, labial palpi yellow, porrect or slightly downward, male antennae bipectinate, yellow along the first fourth, shading to brown toward the apex.

Patagia yellow, tegulae whitish, notum anteriorly yellow, shading backward to whitish. Thorax ventrally yellow.

Forelegs yellow with femur and tibia externally grayish brown, tarsus lighter; mid- and hindlegs yellow with articulation between femur and tibia grayish brown. All praetarsi brown. Spurs formula 0-2-4.

Abdomen yellow.

\section{Genitalia}

MALE. A8 tergum rectangular, slightly shorter than seventh segment; A8 sternum slightly sclerotized, bar-like, arch-shaped, with two apodemal blunt cephalad appendices.

Uncus slender, long, caudally bent, ending in a point; tegument pear-shaped (ventral view); vinculum semicircular, strong, with a median concavity. Juxta great, upside down Y-shaped, well sclerotized.

Basis valvae sclerotized at the junction with the juxta, with which it forms a pseudo-articulation; membranous at supravalvar level.

Ala valvae with ventral margin sclerotized and swollen, dorsal margin membranous.

Supravalva sclerotized with ventral margin membranous.

Distal process of the ala valvae strongly sclerotized, with a triangular process (Fig. 4D, arrow) at the distal third of the valvar length, and a robust hook-like termination ending in a big thorn and dorsally 
covered by slim spines. Distal process of the supravalva less sclerotized than the previous one, large and spatulate.

Aedeagus quite narrow, partially membranous (pseudaedoeagus of Birket-Smith 1965), without coecum; vesica small, with sparse tiny thorns and two lobes, one at the base and one apically on the main lobe (respectively numbered 1 and 2 in Fig. 4D).

\section{Discussion}

The genus Nanna is an entirely African genus, with mainly Western and Central distribution, and it seems to be chiefly associated with a tropical habitat with a high humidity level.

From a strictly systematic point of view, the genus is quite well distinguishable from others by its large wingspan, generally white wing colour and peculiarities in its genital apparatus (see Introduction).

In Gabon, at the moment, it consists of four species; however, given the high biodiversity in other groups (even insects other than moths; Durante, personal observation), it is very probable that the number will increase following future research. Most species, based on present knowledge, occur in Cameroon (six), followed by Gabon (four) and Nigeria (three), due probably to the extension of the recording survey in each country.

\section{Acknowledgements}

Permission to visit and collect in the Gabonese parks was obtained through an international convention established between the CENAREST and the MSNS in order to implement common research projects. The contributions of the IRAF and IRET were fundamental in helping with facilities in the Ipassa Research Station, and the authors thank the following for their important roles in this MSNS collaboration: Daniel Franck Idiata (Commissaire Général of the CENAREST), Auguste NdoutoumeNdong (Director of the IRAF), Alfred Ngomanda (Director of the IRET), Joseph Vivien Okouyi Okouyi (Conservator of the Ivindo National Park) and Aurélie Flore Molouba (Commission Scientifique sur les Autorisations de Recherche of the CENAREST). Many thanks are due to the ANPN for permission to collect material for research purpose in the parks. The authors also thank Piero Carlino, Luca Nocco, Sandro Panzera, and Luigi Potenza of MSNS for their support of the Gabonese research program. This study has been possible thanks to the courtesy of Ugo Dall'Asta and Alice-Marie Busset, RMCA, and of Martin Honey, BMNH. Many thanks are due to Koen Martens, University of Ghent, for very useful suggestions and language revision, and to two anonymous referees for valuable advice. The present paper (marked MSNS-GE3) has been prepared within the Gabonese research program of the MSNS (being the previous paper Bayendi Loudit et al., in prep., marked MSNS-GE2).

\section{References}

Birket-Smith J. 1965. A revision of the West African Eilemic Moths, based on the Male Genitalia. (Lep. Arctiidae, Lithosinae; incl. gen. Crocosia, Eilema, Lithosia, Pelosia, Phryganopsis a. o.). Papers from the Faculty of Science, Series C (Zoology) 1, Haile Sellassie I University, Addis Ababa.

Durante A. 2008. Asuroides, a new genus of lithosiine moths (Lepidoptera, Arctiidae, Lithosiinae). Zootaxa 1713: 53-68.

Durante A. 2012. The genus Afrasura Durante, 2009 in Gabon, with description of five new species and a new species group (Erebidae: Arctiinae: Lithosiini). Zootaxa 3478: 383-398.

Durante M.A. \& Panzera S. 2001. I Lepidotteri del Delta del Niger (secondo contributo) (Lepidoptera, Arctiidae, Lithosiinae). Lambillionea 101 (2): 203-215. 
Hampson G.F. 1900 Catalogue of the Lepidoptera Phalaenae in the British Museum. Vol. 2. Arctiadae (Nolinae, Lithosianae) in the collection of British Museum. Printed by Order of the Trustees, London.

Kühne L. 2005. Neue Taxa und neue Synonyme afrikanischer Arctiidae (Lepidoptera). Lambillionea 105 (3): 486-493.

Kühne L. 2007. Beschreibung neuer Flechtenbärenarten aus Afrika nebst taxonomischen Anmerkungen (Arctiidae: Lithosiinae).In:Pecks H. \& HackerH.(eds) Esperiana Memoir 3:353-394. Wissenschaftlicher Verlag - Pecks, Schwanfeld.

Kiriakoff S.G. 1963. Lepidoptera Heterocera. In: Exploration du Parc National Albert (Deuxième Série) 16 (3): 73-124. Institut des Parcs Nationaux du Congo et du Rwanda, Bruxelles.

Klots A.B. 1970. Lepidoptera. In: Tuxen S.L. (ed.) Taxonomist's Glossary of Genitalia in Insects (2nd rev.): 115-130. E. Munksgaard,Copenhagen.

Kristensen N.P. 2003. Skeleton and muscles: adults. In: Kristensen N.P. (ed.) Lepidoptera, Moths and Butterflies. Vol. 2: Morphology, Physiology, and Development: 39-131. Handbook of Zoology 4 (36), W. de Gruyter, Berlin, New York.

Plötz C. 1880. Verzeichniss der vom Professor Dr. R. Buchholz in West-Afrika gesammelten Schmetterlinge. Entomologische Zeitung 41 (1-3): 76-88.

Strand E. 1912. Zoologische Ergebnisse der Expedition des Herrn G. Tessmann nach Süd-Kamerun und Spanisch-Guinea. Lepidoptera. Archiv für Naturgeschichte, Abteilung A 78 (9): 92-106.

Tikhomirov A.M. 1979. The phylogenetic relationship and classification of European Arctiidae (Lepidoptera) as indicated by the functional morphology of the male genitalia. Entomological Review 58: 63-69.

Vande Weghe G.R. 2010. Papillons du Gabon. Wildlife Conservation Society, Libreville.

Vande Weghe J.P. 2006. Ivindo et Mwagna. Eaux noires, forêts vierges et baïs. Les parcs nationaux du Gabon. Wildlife Conservation Society, Libreville.

Winter W.D. 2000. Basic Techniques for Observing and Studying Moths and Butterflies. Memoir 5, Lepidopterists' Society, Los Angeles.

Manuscript received: 18 July 2013

Manuscript accepted: 21 October 2013

Published on: 22 November 2013

Topic editor: Koen Martens

Desk editor: Charlotte Thionois

Printed versions of all papers are also deposited in the libraries of the institutes that are members of the EJT consortium: Muséum National d'Histoire Naturelle, Paris, France; National Botanic Garden of Belgium, Meise, Belgium; Royal Museum for Central Africa, Tervuren, Belgium; Natural History Museum, London, United Kingdom; Royal Belgian Institute of Natural Sciences, Brussels, Belgium; Natural History Museum of Denmark, Copenhagen, Denmark. 